\title{
Association Between Mitral Valve Prolapse, Migraine, and White Matter Hyperintensities on Magnetic Resonance Imaging
}

\author{
Mitral Kapak Prolapsusu, Migren ve Manyetik Rezonans Görüntülemede Beyaz Cevher
} Hiperintensiteleri Arasındaki İlişki

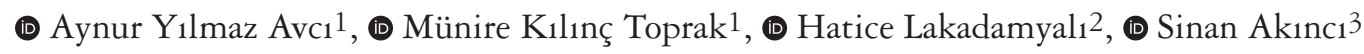 \\ ${ }^{1}$ Baskent University Faculty of Medicine, Department of Neurology, Ankara, Turkey \\ 2Baskent University Faculty of Medicine, Department of Radiology, Ankara, Turkey \\ 3Baskent University Faculty of Medicine, Department of Cardiology, Ankara, Turkey
}

\begin{abstract}
Objective: Migraine is linked with an elevation in vascular risk factors, ischemic stroke, and a variety of constitutional brain lesions. However, the pathogenesis of this relationship is still inexplicit. The link between cardiac diseases and comorbid migraine-ischemic stroke might be a vascular disease involving both heart and brain. In this study, an association between mitral valve prolapse (MVP), migraine, and the presence of brain white matter hyperintensities (WMHs) were evaluated among adult subjects with migraine headache devoid of any traditional vascular risk factors.

Materials and Methods: Four hundred subjects (200 subjects with migraine headache, 200 healthy controls; age range 18-50 years) were incorporated in the retrospective study. Existence of a headache compatible with migraine was diagnosed according to the International Headache Society-2 criteria. The participants were devoid of any known comorbid diseases, vascular risk factors or inflammatory diseases. All patients, both those with migraine and controls were screened with echocardiography to assess for MVP and with brain magnetic resonance imaging to evaluate the presence of any WMHs.

Results: The prevalence of MVP was found to be higher in the migraine group ( $<<0.011)$. The odds ratio (OR) for the presence of MVP in patients with migraine compared with controls was 2.44 [95\% confidence interval (CI): 1.25-4.74; $\mathrm{p}=0.0086$ ]. The OR for the presence of WMHs in patients with migraine compared with controls was 5.88 (95\% CI: 3.42-10.10; $<<0.0001)$. After modifying for confounding factors, multiple linear regression analyses revealed that migraine was independently and positively associated with MVP $(\mathrm{p}=0.044)$, tricuspid regurgitation ( $\mathrm{p}=0.003)$, and WMHs $(\mathrm{p}<0.001)$, and mitral regurgitation and migraine was independently and positively connected with WMHs ( $<<0.005$ and $\mathrm{p}<0.001$, respectively).

Conclusion: MVP is found to be independently associated with migraine when compared with controls. Therefore, we suggest that MVP might have an association with migraine. Nevertheless, we could not demonstrate any correlation between MVP and WMHs. Hence, we suggest that MVP might not be involved in the evolution of WMHs in migraine.
\end{abstract}

Keywords: Headache, vascular risk, cardiovascular risk, magnetic resonance imaging, echocardiography

$\ddot{O} \mathbf{z}$

Amaç: Migren, iskemik inme ve bazı yapısal beyin lezyonları gelişimi gibi vasküler risk faktörlerinde artış ile ilişkilendirilmektedir. Bununla birlikte bu ilişkinin patogenezi halen netleşmemiştir. Kardiyak hastalıklar ve iskemik inme ile komorbidite gösterebilen migrenin bunlarla bağlantısı, hem kalp hem de beyni etkileyen vasküler bir hastalık olması şeklinde açıklanabilir. Bu çalışmada, geleneksel vasküler risk faktörleri olmayan genç-erişkin migren hastalarında mitral kapak prolapsusu (MVP) ile migren ve beyaz cevher hiperintensitesi (BCH) arasındaki ilişki incelendi.

Gereç ve Yöntem: Bu retrospektif çalışmaya 400 olgu alındı (200 migren ve 200 sağ $l_{1} k_{1} l_{1}$ kontrol; yaş aralığı 18-50 yaş). Migren tanısı Uluslararası Baş Ağrısı Toplumu-2 kriterlerine göre kondu. Katılımcıların bilinen vasküler risk faktörleri, enflamatuvar veya eşlikçi başka hastalıkları yoktu. Migrenli kişiler ve sağlıklı kontrollere transtorasik ekokardiyografi yapılarak MVP varlığı; beyin manyetik rezonans görüntüleme yapılarak BCH olup olmadığ1 tarandı.

Bulgular: Migrenli kişilerde MVP prevelansı, kontrollere göre anlamlı yüksek ( $\mathrm{p}<0,011)$ bulundu. Migrenli kişilerde MVP varlı̆̆ odds oranı (OR): 2,44 [\% 95 güven aralığı $(\mathrm{GA}): 1,25-4,74 ; \mathrm{p}=0,0086]$ saptand. Migrenli kişiler ve kontrol grubu BCH varlığı açısından karşılaştırıldığında OR oranı 5,88 (\%95 GA: 3,42-10,10; $\mathrm{p}<0,001)$ bulundu. Karıştırıc1 faktörlere göre uyarlandıktan sonra yapılan çoklu doğrusal regresyon analizleri migrenin, MVP ( $\mathrm{p}=0,044$ ), triküspid yetmezliği $(\mathrm{p}=0,03)$ ve $\mathrm{BCH}$ varlığı $(\mathrm{p}<0,001)$ ile bağımsız, pozitif korele olduğu; migrenin ve mitral yetmezliğin $\mathrm{BCH}$ açısından bağımsız, pozitif korelasyon gösterdiği gözlendi $(\mathrm{p}<0,05, \mathrm{p}<0,001)$.

Address for Correspondence/Yazışma Adresi: Aynur Y1lmaz Avcı MD, Baskent University Faculty of Medicine, Department of Neurology, Ankara, Turkey Phone: +90 5333647434 E-mail: aynuryilmazavci@gmail.com ORCID ID: orcid.org/0000-0001-9004-9382

Received/Gelis Tarihi: 29.01.2018 Accepted/Kabul Tarihi: 08.05.2018

Published in: The preliminary data of this work was presented as an oral poster at the 2015 World Neurology Congress.

${ }^{\circ}$ Copyright 2018 by Turkish Neurological Society

Turkish Journal of Neurology published by Galenos Publishing House. 
Öz

Sonuç: MVP varlı̆̆ı, kontrollerle karşılaştırıldı ̆̆ında migren ile bağımsız ilişkili bulundu. Bu nedenle MVP varlığının, migren ile ilişkili olabileceği düşünüldü. Bununla birlikte, MVP ile BCH arasında pozitif bir korelasyon bulunamadığı için MVP'nin, migrenli olgularda BCH gelişimine bir katkısı olmadı ̆̆ı düşünüldü. Anahtar Kelimeler: Baş ağrısı, vasküler risk, kardiyovasküler risk, manyetik rezonans görüntüleme, ekokardiyografi

\section{Introduction}

Migraine is a very common neurovascular disorder caused by both hereditary $(60 \%)$ and environmental factors $(40 \%)$, affecting nearly $15 \%$ of the population (with a similar prevalence, $16.4 \%$ in Turkey) or about one billion people worldwide $(1,2)$. It was reported to be the second leading cause of disability according to the annually performed "Global Years Lived With Disability" analysis in 2016 (3). Among its high prevalence and disability potency, migraine is also associated with an increase in vascular risk factors (both cardiovascular and cerebrovascular) according to risk prediction score for vascular diseases (4).

However, whether migraine itself is the causative factor or whether the disease is a marker of another underlying cause ending with cardio-and cerebrovascular diseases remains unclear $(3,5,6)$. The suggested "higher prevalence of vascular diseases encompassing both heart and brain" might be due to an augmented presence of vascular endothelial dysfunction or due to a boosting inflammatory response to neurogenic inflammation, elevated prothrombotic factors or due to genetic predisposition. It might also be due to high consumption of anti-migraine medications. Also, the higher manifestation of vascular diseases among patients with migraine might be due to the "higher occurrence of constitutional heart anomalies" such as patent foramen ovale, atrial septal defects, pulmonary arteriovenous malformations, mitral valve prolapse (MVP), atrial septal aneurysm, and congenital heart disease $(5,6,7)$.

MVP is the most frequently detected valvular condition affecting $2-3 \%$ of middle-aged individuals in the general population. Hence, MVP would be expected to affect 176 million people worldwide (8). According to some earlier studies, MVP was considered to be a disease with frequent and serious complications including stroke, atrial fibrillation, heart failure, and mitral regurgitation due to myxomatous degeneration, redundancy of the valve, and supraventricular arrhythmias $(8,9,10)$. However, it was shown to be a benign entity, with a low occurrence of adverse events in a community-based FHS sample (11).

A variety of brain lesions, including white matter hyper intensities (WMHs), and clinically silent infarct-like lesions, localized especially in the posterior circulation have been associated with migraine. Hence, a meta-analysis indicated a four-fold increased risk for the occurrence of these WMHs in people with migraine compared with controls (12). Although these WMHs can also be detected in apparently healthy people, they are frequently regarded as ischemic in origin, and are associated with vascular risk factors. The determining factors in the development of these WMHs are considered to be the lifetime spent with migraine headaches and the frequency of attacks $(13,14)$. However, it is also suggested that conditions as routine risk factors for stroke may lead to tissue damage via vascular endothelial dysfunction or hypercoagulation or embolization, and these might then contribute to the evolution of these WMHs lesions $(5,13,14)$.

There are many developments in the era of migraine pathophysiology and treatment: The underlying mechanism in migraine headache is proposed to be "triggering of the trigemino-vascular system," followed by liberation of calcitonin gene-related peptide" (CGRP) (15). Hence, many trials present strong verification that disturbance of the effects of endogenous CGRP is an effective commence to minimize migraine headaches. However, despite these developments in the pathophysiology of migraine, the mechanism by which it conveys an increased risk for the incidence of WMHs, even "silent infarct-like lesions," is still unclear (16).

We hypothesized that one of the factors responsible for the development of these WMHs in patients with migraine might be "the presence of MVP" in these patients (in case it exists as a comorbid condition). Therefore, we evaluated both the association of MVP with migraine, and the presence of WMHs in subjects with migraine with no traditional vascular risk factors.

\section{Materials and Methods}

\section{Study Design and Patients}

We analyzed data obtained from the records of patients admitted to our outpatient neurology clinic with a diagnosis of headache (compatible with migraine) from June 2014 till December 2016, retrospectively. The patients whose medical records contained both brain magnetic resonance imaging (MRI) and transthoracic echocardiography (ECHO) were included in the study.

Included patients with migraine headache were those with duration of symptoms of $\geq 1$ year, repetition of headache $\geq 2$ attacks/ month, and absence of vascular risk factors along with absences of inflammatory or chronic illnesses such as renal, metabolic, infectious, or immune diseases. Patients with headache duration lasting $<1$ year; those who used analgesics daily or migraine prophylaxis as propranolol, topiramate, or valproic acid; patients with a history of antecedent cerebrovascular or cardiovascular disease, arterial hypertension (blood pressure $>130 / 80 \mathrm{mmHg}$ ), diabetes mellitus, or hyperlipidemia; and those who were pregnant, breast feeding, or on hormonal contraceptives were excluded. Patients using drugs inclusive of antiplatelet agents, anticoagulants, statins, or hormonal drugs were also excluded. Patients who might have possible "symptomatic migraine headache" in whom MRI demonstrated ischemic infarcts, brain tumors, or other conditions that may be affiliated with migraine headache were excluded. Patients with any constitutional heart disease including patent foramen ovale, atrial septal defect, valvular heart disease other than MVP were also excluded. According to these inclusion and exclusion criteria, 200 consecutive patients diagnosed with migraine headache (143 women (71.5\%), 57 men (28.5\%); mean age 33.8 7.6 (range: 18- 
50) years] were recruited as the study group. For the control group, 200 healthy subjects $[131$ women $(65.5 \%), 69$ men $(34.5 \%)$; mean age $33.7 \pm 8.2$ (range: 18 -50) years] were convened from the hospital and laboratory staff, patients' relatives, and the general population. Inclusion criteria for the control subjects were absence of headaches such as migraine, tension-type or cluster headaches; absence of any neurologic or systemic diseases; and matching the patients with migraine in age. The exclusion criteria for the control subjects were the same as for the migraine study group.

Diagnoses of migraine headache were made as stated by the criteria of the International Classification of Headache Disorders-2 (17). Attack histories compatible with migraine were obtained in detail, subsuming disease duration (years), age at onset, repetition of attacks per month, average duration of headache (in hours), activating factors, accompanying manifestations including aura, site and seriousness of pain. The intensity of headache was appraised using a visual analogue scale (VAS) [range, 1 (minimum pain) to 10 (maximum pain)]. Patients were also requested to report the average VAS score. All patients and control subjects were examined thoroughly.

This study was evaluated by the Baskent University Institutional Review Board and due to its retrospective design it was exempted from the requirement for signed informed consent; however, oral informed consent was still taken from all patients.

\section{MRI}

Cerebral MRI (1.5 Tesla MR 355 Inspire; General Electric, SC, USA) with the orbito-meatal line as a reference were performed for all 400 participants. The scans comprised at least three sequences: sagittal T1-weighted, axial T2-weighted, and axial FLAIR images without intravenous contrast. The slice thickness was $5 \mathrm{~mm}$ with a gap of $1 \mathrm{~mm}$. A radiologist who was blinded to the clinical details reviewed and scored all MRI scans.

The scans were evaluated for the existence and characteristics of WMHs, including apparition (focal or confluent), amount, measurements, dissemination (infra or supratentorial), and anatomic position. FLAIR images were used for the determination of the number and size of WMHs; focal punctate hyperintensities $<10 \mathrm{~mm}$ were included, and large confluent hyperintensities ( $>9 \mathrm{~mm}$ ) were excluded. No WMHs were detected in the corpus callosum. Periventricular WMHs were defined as those touching the ventricular system; juxtacortical WMHs were defined as those touching the cortical structures; all others were considered subcortical (18).

The subjects whom brain MRI revealed WMHs, were evaluated with laboratory tests for vasculitis (anticardiolipin antibodies, antinuclear antibody, lupus anticoagulant, anti-double-stranded DNA autoantibody, and C3 and C4 levels).

\section{Echocardiographic Methods}

All subjects underwent standard transthoracic ECHO (TTE) in accordance with the guidelines of the American Society of $\mathrm{ECHO}$, which was performed by an experienced cardiologist who was blinded to any previous MVP diagnosis and clinical history (19). TTE was performed using a GE Health-Care Ultrasound Cardiology device containing a $3.5-\mathrm{MHz}$ transducer. A diagnosis of MVP was made in case during systole, the view of parasternal long-axis displayed any superior displacement of mitral leaflets (one or more) exceeded $2 \mathrm{~mm}$ beyond a line attaching the annular hinge points to the left atrium (20). At the same time, TTE was also used to rule out the existence of any valvular heart diseases other than MVP, atrial septal defects, patent foramen ovale, systolic dysfunction, or other constitutional heart diseases.

\section{Statistical Analyses}

We performed the statistical analyses with IBM SPSS for Windows version 22.0. The Shapiro-Wilk test was used for the evaluation of the normality of continuous variables. The MannWhitney $\mathrm{U}$ test was used for the assessment of differences between two groups, the independent samples t-test was used for continuous variables, and Pearson's chi-square or Fisher's exact test were used for categorical variables. Factors affecting migraine, MVP, and WMHs were identified using multiple logistic regression analyses. Significance was considered if a $\mathrm{p}$ value was less than 0.05 . For the presentation of continuous variables, mean \pm standard deviation or median (range) were used. Categorical variables are reported as frequencies and percentages.

\section{Results}

The characteristics of the patients with migraine headache and characteristics of the control groups are depicted in Table 1. The odds ratio (OR) of MVP in patients with migraine headache was 2.44 [95\% confidence interval (CI): 1.25-4.74; $\mathrm{p}=0.086$, and the OR of WMHs in association with migraine was 5.88 (95\% CI: 3.42-10.10; $<<0.001$ ). There was statistically significant difference between the sex of subjects with migraine because the number of female subjects was higher than for male subjects. Another statistically significant difference was found in the duration of migraine attacks with aura; the duration of attacks was longer than the duration of attacks without aura (Table 2). Except for these, there was no statistically significant differences between the characteristics of migraine headache, findings in $\mathrm{ECHO}$ or in the presence and localization of WMHs in migraine with and without aura group (Table 2).

After modifying for confounding factors, linear regression analyses disclosed that migraine headaches were independently and positively connected with MVP $(\mathrm{p}=0.044)$, tricuspid regurgitation $(\mathrm{p}=0.003)$, and WMH $(\mathrm{p}<0.001)$ (Table 3).

According to univariate analyses, MVP and mitral regurgitation were found to be significantly correlated $(r=0.482, p<0.001)$. After regulating for confounding factors, multivariate logistic regression analyses revealed that mitral regurgitation was independently and positively correlated with MVP (Table 3). However, MVP was not significantly correlated with migraine characteristics or the presence or number of WMH (Table 3).

After altering for confounding factors, multivariate logistic regression analyses showed that WMH were independently and positively associated with female sex, age, migraine headaches, mitral regurgitation, and smoking compared with the normal brain MRI group (Table 3).

When the participants were subdivided into groups with and without WMH (Table 4), the presence of WMH was found to be significantly associated with older age, female sex, smoking, mitral regurgitation, tricuspid regurgitation, duration of migraine headache, and the frequency of migraine attacks (Table 4). 
Table 1. Characteristics of the study participants with migraine and controls*

\begin{tabular}{|c|c|c|c|}
\hline & $\begin{array}{l}\text { Control } \\
(\mathrm{n}=200)\end{array}$ & $\begin{array}{l}\text { Migraine } \\
(\mathrm{n}=200)\end{array}$ & $\mathrm{p}$ \\
\hline Age (years) & $33.7 \pm 8.2$ & $33.8 \pm 7.6$ & NS \\
\hline Sex (female/male) & $\begin{array}{l}131 / 69 \\
(65.5 \% / 34.5 \%)\end{array}$ & $\begin{array}{l}143 / 57 \\
(71.5 \% / 28.5 \%)\end{array}$ & NS \\
\hline Ejection fraction & $66.0 \pm 4.4$ & $65.4 \pm 4.5$ & NS \\
\hline $\begin{array}{l}\text { Mitral valve } \\
\text { prolapse }\end{array}$ & $14(7 \%)$ & $31(15.5 \%)$ & 0.011 \\
\hline Mitral regurgitation & $26(13 \%)$ & $44(22 \%)$ & 0.018 \\
\hline $\begin{array}{l}\text { Tricuspid } \\
\text { regurgitation }\end{array}$ & $8(4 \%)$ & $31(15.5 \%)$ & $<0.001$ \\
\hline Atrial regurgitation & - & $8(4 \%)$ & 0.007 \\
\hline $\begin{array}{l}\text { Presence of WMHs } \\
\text { (\%) }\end{array}$ & $20(10 \%)$ & $79(39.5 \%)$ & $<0.001$ \\
\hline $\begin{array}{l}\text { Presence of } \\
\text { juxtacortical WMHs }\end{array}$ & $8(40 \%)$ & $48(60.8 \%)$ & NS \\
\hline $\begin{array}{l}\text { Presence of } \\
\text { subcortical WMHs }\end{array}$ & $18(90 \%)$ & $77(97.5 \%)$ & NS \\
\hline $\begin{array}{l}\text { Presence of } \\
\text { periventricular } \\
\text { WMHs }\end{array}$ & - & $16(20.3 \%)$ & - \\
\hline $\begin{array}{l}\text { Presence of } \\
\text { infratentorial WMHs }\end{array}$ & - & $14(17.7 \%)$ & - \\
\hline Number of WMHs & $2(1-6)$ & $5(1-15)$ & $<0.001$ \\
\hline $\begin{array}{l}\text { Number of } \\
\text { juxtacortical WMHs }\end{array}$ & $0(0-2)$ & $1(0-8)$ & 0.017 \\
\hline $\begin{array}{l}\text { Number of } \\
\text { subcortical WMHs }\end{array}$ & $2(0-5)$ & $3(0-13)$ & 0.010 \\
\hline $\begin{array}{l}\text { Number of } \\
\text { periventricular } \\
\text { WMHs }\end{array}$ & - & $0(0-4)$ & 0.029 \\
\hline $\begin{array}{l}\text { Number of } \\
\text { infratentorial WMHs }\end{array}$ & - & $0(0-3)$ & 0.044 \\
\hline Aura & - & $64(32 \%)$ & - \\
\hline $\begin{array}{l}\text { Migraine disease } \\
\text { duration (years) }\end{array}$ & - & $5(1-30)$ & - \\
\hline $\begin{array}{l}\text { Headache frequency } \\
\text { (no/month) }\end{array}$ & - & $3(2-13)$ & - \\
\hline $\begin{array}{l}\text { Headache duration } \\
\text { (h) }\end{array}$ & - & $24(1-96)$ & - \\
\hline $\begin{array}{l}\text { Visual analogue } \\
\text { scale score }\end{array}$ & - & $8(4-10)$ & - \\
\hline $\begin{array}{l}\text { Smoking ( } \leq \text { pack/ } \\
\text { day) }\end{array}$ & $33(16.5 \%)$ & $41(20.5 \%)$ & NS \\
\hline \multicolumn{4}{|c|}{$\begin{array}{l}\text { "Data are reported as number }(\%), \text { mean } \pm \text { standard deviation, or median } \\
\text { (range). } \\
\text { WMHs: White matter hyperintensities, NS: Not significant }(\mathrm{p}>0.05)\end{array}$} \\
\hline
\end{tabular}

Table 2. Characteristics of the migraine participants with and without aura*

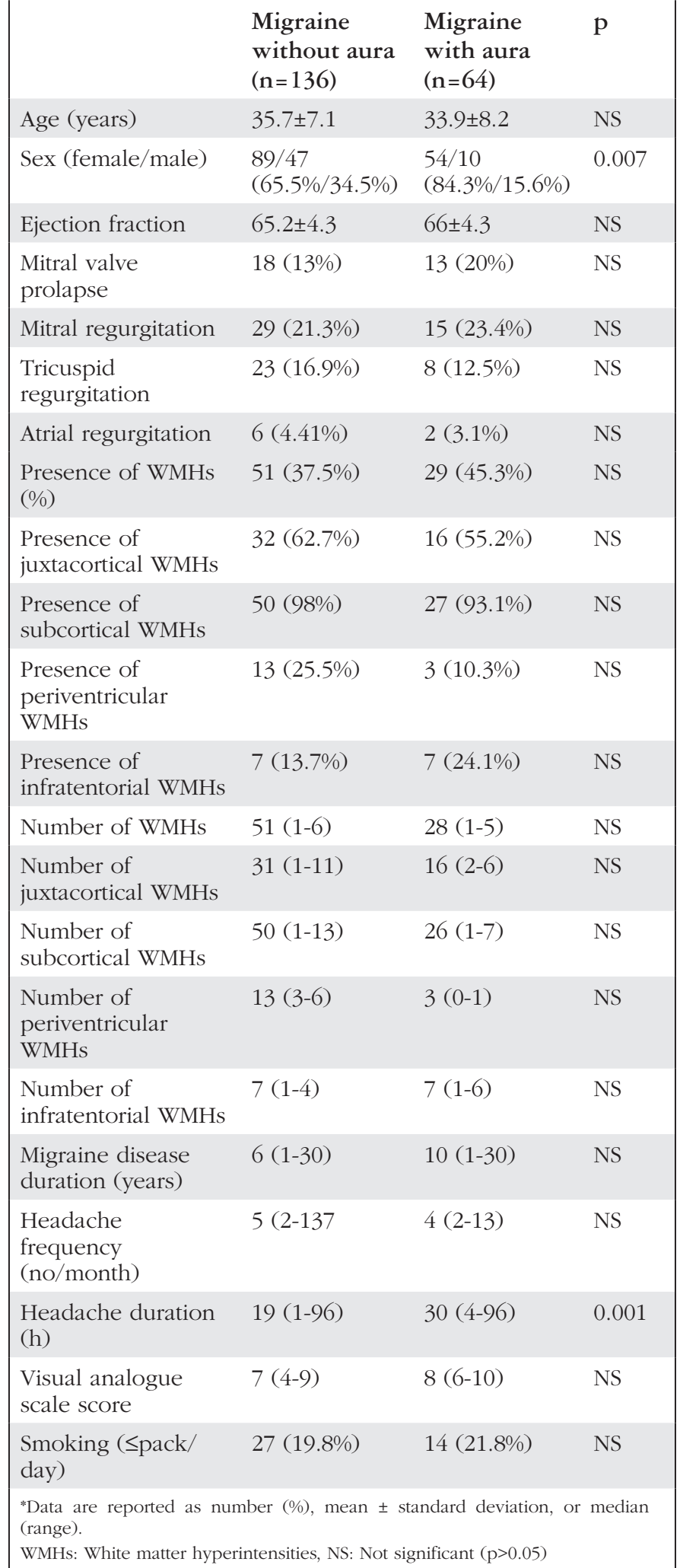


Table 3. Factors affecting migraine, mitral valve prolapse, and white matter hyperintensities*

\begin{tabular}{|c|c|c|c|c|}
\hline & & $\begin{array}{l}\text { Odds } \\
\text { ratio }\end{array}$ & $\begin{array}{l}95 \% \\
\text { confidence } \\
\text { interval }\end{array}$ & $\mathrm{p}$ \\
\hline \multirow{3}{*}{ Migraine } & $\begin{array}{l}\text { Mitral valve } \\
\text { prolapse }\end{array}$ & 2.079 & $1.021-4.234$ & 0.044 \\
\hline & $\begin{array}{l}\text { Tricuspid } \\
\text { regurgitation }\end{array}$ & 3.583 & $1.542-8.327$ & 0.003 \\
\hline & $\begin{array}{l}\text { White matter } \\
\text { hyperintensities }\end{array}$ & 5.499 & $3.171-9.534$ & $<0.001$ \\
\hline \multirow{5}{*}{$\begin{array}{l}\text { White matter } \\
\text { hyperintensities }\end{array}$} & Sex (female) & 2.412 & $1.301-4.473$ & 0.005 \\
\hline & $\begin{array}{l}\text { Mitral } \\
\text { regurgitation }\end{array}$ & 2.395 & $1.306-4.391$ & 0.005 \\
\hline & Migraine & 5.740 & $3.265-10.090$ & $<0.001$ \\
\hline & Age & 1.052 & $1.018-1.088$ & 0.003 \\
\hline & Smoking & 2.158 & $1.146-4.065$ & 0.017 \\
\hline
\end{tabular}

Table 4. Characteristics according to the presence of white matter hyperintensities on magnetic resonance imaging*

\begin{tabular}{|c|c|c|c|}
\hline & $\begin{array}{l}\text { WMHs } \\
\text { absent } \\
(\mathrm{n}=301)\end{array}$ & $\begin{array}{l}\text { WMHs } \\
\text { present } \\
(\mathrm{n}=99)\end{array}$ & $\mathrm{p}$ \\
\hline Age (years) & $33.1 \pm 7.9$ & $35.6 \pm 7.7$ & 0.006 \\
\hline Ejection fraction & $65.7 \pm 4.5$ & $65.8 \pm 4.3$ & NS \\
\hline Sex (female/male) & $\begin{array}{l}107 / 194 \\
(35.5 \% / 64.5 \%)\end{array}$ & $\begin{array}{l}19 / 80 \\
(19.2 \% / 80.8 \%)\end{array}$ & 0.004 \\
\hline $\begin{array}{l}\text { Smoking ( } \leq \text { pack/ } \\
\text { day) }\end{array}$ & $49(16.3 \%)$ & $25(25.3 \%)$ & 0.046 \\
\hline Mitral regurgitation & $40(13.3 \%)$ & $30(30.3 \%)$ & $<0.001$ \\
\hline $\begin{array}{l}\text { Tricuspid } \\
\text { regurgitation }\end{array}$ & $23(7.6 \%)$ & $16(16.2 \%)$ & 0.022 \\
\hline Atrial regurgitation & $4(1.3 \%)$ & $4(4 \%)$ & NS \\
\hline $\begin{array}{l}\text { Mitral valve } \\
\text { prolapse }\end{array}$ & $30(10 \%)$ & $15(15.2 \%)$ & NS \\
\hline Aura & $36(29.8 \%)$ & $28(35.4 \%)$ & NS \\
\hline $\begin{array}{l}\text { Migraine disease } \\
\text { duration (years) }\end{array}$ & $4(1-30)$ & $10(1-30)$ & 0.024 \\
\hline $\begin{array}{l}\text { Headache } \\
\text { frequency (no/ } \\
\text { month) }\end{array}$ & $3(2-13)$ & $4(2-13)$ & 0.011 \\
\hline $\begin{array}{l}\text { Headache duration } \\
\text { (hours) }\end{array}$ & $24(1-96)$ & $24(4-96)$ & NS \\
\hline $\begin{array}{l}\text { Visual analogue } \\
\text { scale score }\end{array}$ & $7(5-10)$ & $8(4-10)$ & NS \\
\hline \multicolumn{4}{|c|}{$\begin{array}{l}\text { "Data are reported as number }(\%) \text {, mean } \pm \text { standard deviation, or median } \\
\text { (range). } \\
\text { MRI: Magnetic resonance imaging, WMHs: White matter hyperintensities, NS: } \\
\text { Not significant }(\mathrm{p}>0.05)\end{array}$} \\
\hline
\end{tabular}

\section{Discussion}

A high prevalence of MVP and migraine comorbidity (as 20$59 \%$ ) has been shown (21). Many brain MRI studies reported a relatively high prevalence of subclinical $\mathrm{WMH}$ in patients with migraine headache $(13,14,22)$. Regarding these data, we wanted to evaluate the relation between MVP and migraine in conjunction with WMHs.

Our study also demonstrated that a higher number of patients with migraine headache encountered MVP and mild valve regurgitation compared with the control group $(\mathrm{p}=0.044)$. There was no statistically significant difference between MVP and migraine attacks with or without aura (Table 1,2). The risk for MVP was 2.4-fold higher in patients with migraine than controls (OR: 2.44; 95\% CI: 1.25-4.74; p=0.0086) (Table 3). Although mild mitral regurgitation was found to be independently associated with WMH, no association could be elicited between MVP and the presence of WMHs (Table 3).

Our results are in line with previous studies reporting MVP to be more frequent in subjects with migraine headache than in controls $(21,23)$, although there are some conflicting results $(24,25)$. The sample group was quite small in one study, and the mean age of the participants in another study was older than in our study, and no data were included on vascular risk factors $(24,25)$.

In our study, the prevalence of MVP was found as $15.5 \%$ in subjects with migraine headaches, similar to the reported prevalence of MVP in the literature $(15-25 \%)(8,23)$. A previous study reported that $27.8 \%$ patients with MVP had migraine headache, which was significantly higher than the expected number in the general population (approximately 10\%) (26).

Although several mechanisms have been suggested regarding the causal association between the generation of migraine headaches and the development of MVP, the underlying mechanism is still obscure. It is suggested that shortened platelet survival and loss of endothelial continuity could initiate platelet activation and aggregation $(21,23)$. As such, migraine headaches could be generated following the release of serotonin from these aggregated platelets (7,23). Paroxysmal arrhythmias that may accompany MVP syndrome may also increase the likelihood of embolization, leading to the formation of silent infarct-like lesions or WMHs (27).

Migraine headache is reported to be a risk factor for development of WMHs and the prevalence of WMHs in patients with migraine ranges from $14 \%$ to $59 \%(13,28,29)$. One suggested mechanisms for this is "oligemia triggered by repeated and prolonged periods of migraine attacks affecting the vulnerable small deep penetrating arteries" $(13,28)$. In the present study, WMHs were detected 5.88 times more frequently in patients with migraine headaches than in controls, and we also showed that the presence of WMHs increased according to the (increased) headache frequency and duration, concordant with previous studies (Table 4). The association between WMHs and both the duration and frequency of migraine attacks suggest that the "migraine attack" itself plays a role in the pathophysiology.

Mitral regurgitation and other co-factors (such as age, female sex, mitral regurgitation, and smoking) are found to be independent factors associated with WMH (Table 3). Hence, these co-factors may also contribute to the pathophysiology of WMH. 
Therefore, the relationship between mitral regurgitation and WMH still merits further investigation.

In this study, the anatomic location of WMHs differed between the groups. In subjects with migraine headache, WMHs were mostly located in the subcortical region, less juxtacortically; and only subjects with migraine headache had WMHs located in the periventricular and infratentorial regions (Table 1). These findings are in line with previous studies $(13,28,29)$. However, in contrast to our findings, in another study no differences in the location of deep and periventricular WMHs could be elicited between migraineurs and controls (14). Accordingly, there may be different mechanisms affecting the development of these lesions in association with migraine. Hence, some previous studies included participants older in age with higher vascular risk factors (14). There are also studies reporting no increased number of WMHs in association with migraine compared with controls $(30,31)$, but those studies had either smaller sample numbers than ours or included no information about the vascular risk factors of their participants $(30,31)$.

MVP is a common decadence cardiac valvulopathy of unknown etiology inclining to mitral regurgitation, heart failure, and even sudden fatality. Subjects with MVP have a greater chance to experience mitral regurgitation than those without, even if the valvular regurgitation is trace or mild $(11,32)$. The prevalence of mild mitral regurgitation was $68.9 \%$ in our study, consistent with previous reports (11). The most common complication of MVP is worsening of the mitral regurgitation. It causes diastolic dysfunction of the left atrium and left ventricle, cardiac arrhythmias, and subsequent heart failure, with an increased risk for infective endocarditis. Hence, $2.4 \%$ of patients with MVP experience thromboembolic events (33).

As far as we know, our study is the first to display a connection between MVP and WMHs in migraine. The unique feature of our study design was the simultaneous assessment of an association between MVP and WMH in migraine. In order to minimize the effects of age-dependent WMHs, we included patients aged <50 years who were devoid of any vascular risk factors or inflammatory diseases.

\section{Study Limitations}

There are many limitations of our study, such as its retrospective design and lack of trans-esophageal ECHO examination, because it is a better tool for diagnosing MVP. Furthermore, we could not strictly exclude risk factors such as smoking and obesity; we excluded heavy smokers ( $>1$ pack/day), but did not exclude all cigarette smokers. However, there were no significant differences in smoking habits between the subjects with migraine and controls. We did not calculate the body mass indexes of the participants, which might also give more information. The association between migraine, WMHs, and MVP might have been evaluated further if we could have studied markers of thrombosis and coagulation factors in detail.

\section{Conclusion}

We found that MVP was independently associated with migraine headache, but we found no correlation between MVP and WMHs. We suggest that MVP is not causally involved in the development of WMHs associated with migraine headache. Further prospective studies should evaluate the relationships between migraine, WMHs, and MVP.

\section{Acknowledgements}

The authors thank Hakan Gökahmetoğlu for helping with data collection.

\section{Ethics}

Ethics Committee Approval: This was a retrospective study, no ethical committee approval was taken. All procedures performed in studies involving human participants were in accordance with the ethical standards of the institutional and/ or national research committee and with the 1964 Helsinki Declaration and its later amendments or comparable ethical standards.

Informed Consent: This study was deemed to be exempt from the requirement for informed consent by the Institutional Review Board of Baskent University due to its retrospective design.

Peer-review: Externally peer-reviewed.

\section{Authorship Contributions}

Concept: A.Y.A., M.K.T., Design: A.Y.A., M.K.T., Data Collection or Processing: A.Y.A., M.K.T., H.L., S.A., Analysis or Interpretation: A.Y.A., Literature Search: A.Y.A., M.K.T., Writing: A.Y.A., M.K.T.

Conflict of Interest: The authors declare that they have no conflict of interest.

Financial Disclosure: The authors declared that this study received no financial support.

\section{References}

1. Ertas M, Baykan B, Kocasoy OE, et al. One-year prevalence and the impact of migraine and tension-type headache in Turkey: A nationwide home-based study in adults. J Headache Pain 2012;13:147-157.

2. Lipton RB, Bigal ME, Damond M, Freitag F, Reed ML, Stewart WF; AMPP Advisory Group. Migraine prevalence, disease burden, and the need for preventive therapy. Neurology 2007;68:343-349.

3. Adelborg K, Szepligeti SK, Holland-Bill L, et al. Migraine and risk of cardiovascular diseases: Danish population based matchedcohort study. BMJ 2018;360:k96

4. Spector JT, Kahn SR, Jones MR, Jayakumar M, Dalal D, Nazarian S Migraine headache and ischemic stroke risk: an updated meta-analysis. Am J Med 2010;123:612-624.

5. Tietjen GE. Migraine and ischaemic heart disease and stroke: Potential mechanisms and treatment implications. Cephalalgia 2007;27:981-987.

6. Kurth T, Ridker PM, Buring JE. Migraine and biomarkers of cardiovascular disease in women. Cephalalgia 2007;28:49-56.

7. Schwedt T. The migraine association with cardiac anomalies, cardiovascular disease and stroke. Neurol Clin 2009;27:513-523.

8. Delling FN, Vasan RS. Epidemiology and pathophysiology of mitral valve prolapse: New insight into disease progression, genetics, and molecular basis. Circulation 2014:;27:2158-2170.

9. Zuppiroli A, Rinaldi M, Kramer-Fox R, Favilli S, Roman MJ, Devereux RB. Natural history of mitral valve prolapse. Am J Cardiol 1995;75:10281032.

10. Heck AF. Neurologic aspects of mitral valve prolapse. Angiology 1989; 40:743-751.

11. Freed LA, Levy D, Levine RA, et al. Prevalence and clinical outcome of mitral valve prolapse. New Engl J Med 1999;341:1-7.

12. Swartz RH, Kern RZ. Migraine is associated with magnetic resonance imaging white matter abnormalities: a meta-analysis. Arch Neurol 2004;61:1366-1368. 
13. Kurth T, Mohammed S, Maillard P, et al. Headache, migraine, and structural brain lesions and function: Population based epidemiology of vascular agingMRI study. BMJ 2011;342:c7357.

14. Kruit MC, Buchem MA, Launer LJ, Terwindt GM, Ferrari MD. Migraine is associated with an increased risk of deep white matter lesions, subclinical posterior circulation infarcts and brain iron accumulation: The populationbased MRI CAMERA study. Cephalalgia 2010;30:129-136.

15. Ferrari MD, Klever RR, Terwindt GM, Ayata C, van den Maagdenberg AM Migraine pathophysiology: lessons from mouse models and human genetics. Lancet Neurol 2015;14:65-80.

16. Edvinsson L. CGRP receptor antagonists and antibodies against CGRP and its receptor inmigraine treatment. Br J Clin Pharmacol 2015;80:193-199.

17. Headache Classification Subcommittee of the International Headache Society. The International Classification of Headache Disorders 2nd edition. Cephalalgia 2004;24:1-160.

18. Barkhof F, Filippi M, Miller DH, et al. Comparison of MRI criteria at first presentation to predict conversion to clinically definite multiple sclerosis. Brain 1997;120:2059-2069.

19. Lang RM, Bierig M, Devereux RB, et al; Chamber Quantification Writing Group; American Society of Echocardiography's Guidelines and Standards Committee; European Association of Echocardiography. Recommendations for chamber quantification: A report from the American Society of Echocardiography's Guidelines and Standards Committee and the Chamber Quantification Writing Group, developed in conjunction with the European Association of Echocardiography, a branch of the European Society of Cardiology. J Am Soc Echocardiogr 2005;18:1440-1463.

20. Devereux RB, Kramer-Fox R, Shear MK, Kligfield P, Pini R, Savage DD. Diagnosis and classification of severity of mitral valve prolapse: Methodologic, biologic, and prognostic considerations. Am Heart J 1987;113:1265-1280.

21. Termine C, Trotti R, Ondei P, et al. Mitral valve prolapse and abnormalities of hemostasis in children and adolescent with migraine with aura and other idiopathic headaches: A pilot study. Acta Neurol Scand 2010;122:91-96.
22. Del Sette M, Dinia L, Bonzano L, et al. White matter lesions in migraine and right-to-left shunt: A conventional and diffusion MRI study. Cephalalgia 2008;28:376-382.

23. Spence JD, Wong D, Melendez LJ, Nichol PM, Brown JD. Increased prevalence of mitral valve prolapse in patients with migraine. Can Med Assoc J 1984;131:1457-1460.

24. Domitrz I, Styczynski G, Wilczko J, Marczewska MM, Domitrz W, Kaminska A. An association between migraines and heart anomalies-true or false? A heart ultrasound study using cTTE in migraine patients and control participants. Pain Medicine 2014;15:2156-2160.

25. Pfaffenrath V, Kommissari I, Pollman W, Kaube H, Rath M. Cerebrovascular risk factors in migraine with prolonged aura and without aura. Cephalalgia 1991;11:257-261.

26. Litman GI, Friedman HM. Migraine and the mitral valve prolapse syndrome Am Heart J 1978;96:610-614.

27. Blum A, Shapira Y, Yeganh S, Rabinkov M. Mitral valve prolapse and thromboembolic events. Isr Med Assoc J 2001;3:282-283.

28. Seneviratne U, Chong W, Billimoria PH. Brain white matter hyperintensities in migraine: Clinical and radiological correlates. Clin Neurol Neurosurg 2013;115:1040-1043

29. Avci AY, Lakadamyali H, Arikan S, Benli US, Kilinc M. High sensitivity C-reactive protein and cerebral white matter hyperintensities on magnetic resonance imaging in migraine patients. J Headache Pain 2015;16:9.

30. Galli A, Di Fiore P, D'Arrigo G, et al. Migraine with aura white matter lesions: preliminary data on clinical aspects. Neurol Sci 2017;38(Suppl 1):710 .

31. Uggetti C, Squarza S, Longaretti F, et al. Migraine with aura and white matter lesions: An MRI study. Neurol Sci 2017;38(Suppl 1):11-13.

32. Arvierinos JF, Gersh BJ, Melton LJ, et al. Natural history of asymptomatic mitral valve prolapse in the community. Circulation 2002;106:1355-1361.

33. Jonkaitiene R, Benetis R, Ablonskyte-Dudoniene $\mathrm{R}$, Jurkevicius $\mathrm{R}$. Mitral valve prolapse: Diagnosis, treatment and natural course. Medicina 2005; $41: 325-334$. 